Peasants in Revolt 
THIS PAGE INTENTIONALLY LEFT BLANK 
Latin American Monographs, No. 28 Institute of Latin American Studies The University of Texas at Austin 
THIS PAGE INTENTIONALLY LEFT BLANK 


\section{PEASANTS IN REVOLT A Chilean Case Study, 1965-1971}

James Petras and Hugo Zemelman Merino

Translated by Thomas Flory

PUBLISHED FOR THE INSTITUTE OF LATIN AMERICAN STUDIES BY THE UNIVERSITY OF TEXAS PRESS, AUSTIN 
Library of Congress Cataloging in Publication Data

Petras, James F 1937-

Peasants in revolt.

(Latin American monographs, no. 28)

Translated from the author's unpublished $\mathrm{ms}$.

1. Peasantry-Chile-Case studies. 2. Peasant uprising-Chile-Case studies. 3. Political participation-Chile-Case studies. I. Zemelman Merino, Hugo, 1931- joint author. II. Title.

III. Series: Latin American monographs (Austin, Tex.)

no. 28.

HD506.P4813 322.4' $2^{\prime} 0983 \quad 72-1578$

ISBN 0-292-76404-9

Copyright $\odot 1972$ by James F. Petras and Hugo Zemelman Merino

All Rights Reserved 
Dedicated to the memory of MAURICE LEFEVBRE

friend, scholar, and fighter 
THIS PAGE INTENTIONALLY LEFT BLANK 